\title{
LANGUAGE LEARNING STRATEGIES OF UNDERGRADUATE EFL STUDENTS
}

\author{
Mega Lestari ${ }^{1}$, Achmad Yudi Wahyudin ${ }^{2}$ \\ Universitas Teknokrat Indonesia ${ }^{1,2}$
}

tari4mega4@gmail.com ${ }^{1}$,achmad.yudi@teknokrat.ac.id ${ }^{2}$

\begin{tabular}{lll}
\hline Received: 10 May 2020 & Accepted: 14 June 2020 & Published: 27 June 2020 \\
\hline
\end{tabular}

\begin{abstract}
This study attempts to explore the language learning strategies used by the students' who take English Literature study programs in English as a foreign language (EFL) setting. This study involves 76 participants asked to fulfill a questionnaire called Strategy Inventory for Language Learning (SILL) developed by Oxford (1990). The result of this research showed that metacognitive has been the most frequently used strategy followed by social and compensation strategies while affective strategies become the least strategy used by the students. This research could be meaningful insight for other researches or the students to analyze the language learning strategies used by the students and be meaningful to know the language learning strategies that appropriate especially in the field of the second language.
\end{abstract}

Keywords: language learning strategies, EFL, strategy inventory for language learning.

\section{To cite this article:}

Lestari, M. \& Wahyudin, A. Y. (2020). Language Learning Strategies of Undergraduate EFL Students. Journal of English Language Teaching and Learning, 1(1), 25-30.

\section{INTRODUCTION}

In the last decades, there are some researches in the field of the second language (L2) teaching and learning has shifted from instructional methods to some learner characteristics due to the development of technology in the education field (Sari and Wahyudin, 2019). The growth development of technology has embraced valuable parts of language learning at all education levels to improve the quality of teaching and learning processes and make learners independent (Sari and Wahyudin, 2019; Aminatun and Oktaviani, 2019). Every learner employs certain strategies and styles (Wahyudin and Rido, 2020) to support the attainment of language learning objectives (Ayu, 2018; Mandasari and Oktaviani, 2018). This statement is in line with Abdelheim (2015) who states that "there was an awareness that aptitude was not the governing factor in language learning success implying that language achievement depends quite heavily on the individual learner's endeavors. This led to greater interest in how individual learners approach and control their learning and use of language."

Oxford (1990) mentions that there are full Learning Language Strategies (LLS). The first, direct strategies include point one for creating mental linkages, applying images and sound, reviewing well, and employing action. Second, cognitive strategies are related to, practicing, receiving and sending messages, analyzing and reasoning, and creating a structure for input and output (Wong and Nunan, 2011). Third, compensation strategies deal with, guessing intelligently, and overcoming limitations in speaking and writing. The fourth, indirect strategies include metacognitive strategies related to centering our learning, arranging and planning our learning, and evaluating our learning. The fifth, affective strategies are the attempt to lower our anxiety, encouraging ourselves, and managing our emotional temperature. At last, social strategies cover, asking questions, cooperating with others, emphasizing with others. On the other hand, in the study from Mandasari and Oktaviani (2018), it is mentioned clearly that most students used language learning strategies including affective, memory, social, metacognitive, cognitive, and compensation.

Thus, this paper is a modest attempt to bring a broader discussion about defining the strategies that used by students in their learning, however, being aware of the characteristics, techniques, and strategies of a good language learner facilitate students' language learning and help them enhance learning efficiency especially in the undergraduate level. This research will help practitioners identify the language learning strategies that appropriate to be taught to the students. Besides this research benefits the students so that they realize their learning strategies and they can employ it more effectively and efficiently to support their target language mastery. 


\section{METHOD}

Participants

The participants of the study are selected from a total of 200 populations consisting of male and female from the second-year students in one of the private universities in Bandar Lampung. After randomly selected, the sample of the research is 76 students. The age of the students ranged from 20 to 25 years, with a mean of 22 years. They never studied abroad and stayed in English-speaking countries beforehand. All the subjects had studied English for at least six years in the intermediate and secondary schools. $98 \%$ of the subjects reported that they have never learned English outside of their formal education and their native language is not English.

\section{Instruments}

The instrument of this research used a modified version of the Strategy Inventory for Language Learning (SILL) administered to examine the types and frequency of use of language learning strategies (Oxford, 1990). The SILL has been employed as a key instrument in numerous studies. A Cronbach's alpha calculated for this study also revealed acceptable reliability. In the SILL, language learning strategies are grouped into six categories for assessment: memory strategies, cognitive strategies, compensation, metacognitive strategies, affective strategies, and social strategies. The Indonesian version of the questionnaire was discussed and checked by professional Indonesian teachers to avoid any ambiguity in the wording of the questionnaire and to ensure content validity. The questionnaire consisted of 50 items to which students were asked to respond on a 5-point Likert scale, ranging from 1 to 5. A range of 3.5-5 is thought to reflect high use of that strategy, 2.5-3.4 medium use, and 1.02.4 low use of strategy (Oxford, 1990). Besides, a semi-structured interview was also used to confirm the result of LLS use of the students.

\section{Data Collection and Analysis}

The questionnaire was administered to the students in the classroom and also via email. The students were told that there were no right or wrong answers to any question, their confidentiality was secured, and their responses would be used for research purposes only. They were also informed that their participation would not affect their grades, and they still had the option not to participate. The data was analyzed using SPSS 19.0. to explore frequency means the standard deviation, as well as the participants' demographic information.

\section{FINDINGS AND DISCUSSION}

This study was conducted to explore the students' language learning strategies at the undergraduate level. There are five categories of language learning strategies explored in this study. They are memory strategies, cognitive strategies, metacognitive strategies, compensation strategies, effective strategies, and social strategies. The findings show that students equally use those five strategies.

Table 1. Language Learning Strategies used by the students.

\begin{tabular}{lc}
\hline \multicolumn{1}{c}{ Category } & mean \\
\hline Metacognitive strategies & 3.78 \\
Social strategies & 3.73 \\
Compensation strategies & 3.54 \\
Cognitive strategies & 3.31 \\
Memory strategies & 3.13 \\
Affective strategies & 3.12 \\
\hline
\end{tabular}

Table 1. highlights that all strategies are rather equally used by the students at the tertiary level. The most frequent strategy is metacognitive strategies, while the least strategies used by the students are effective strategies. Each category then is analyzed to know which typical strategies frequently used by the students. From the questionnaire analysis students tend to think the relationships between what they have already known and new things they learn in English (4.1) in memory strategies, while the least strategy used by the students is using rhymes to remember new English words (2.8).

Table 2. Memory strategies used by the students

\begin{tabular}{|c|c|c|}
\hline Strategy & Mean & SD \\
\hline I think of relationships between what I already know and the new things I learn in English. & 4.1 & 0.69 \\
\hline I use new English words in a sentence so I can remember them & 3.7 & 0.81 \\
\hline I connect the sound of a new English word and an image or picture of the word to help me remember the word & 3.4 & 0.51 \\
\hline I remember a new English word by making a mental picture of a situation in which the word might be used & 3.1 & 0.91 \\
\hline I use rhymes to remember new English words & 2.8 & 0.83 \\
\hline I use flashcards to remember new English words & 2.67 & 0.77 \\
\hline I physically act out new English words & 3.4 & 1.08 \\
\hline
\end{tabular}




\begin{tabular}{l}
\hline I review English lessons often \\
$\begin{array}{l}\text { I remember new English words or phrases by remembering their location on the page, on the board, or a street } \\
\text { sign }\end{array}$
\end{tabular}

The memory strategies table shows that the students often think of a link between what they are learning and what they have learned before. They do not prefer using rhymes or using flashcards to remember new English words. The students know the new word and try to remember the word from objects that in outside places such as street, building, and store. They do not try a new method of learning English like using flashcard they only do what they do before. The highest score of memory strategies is for "I review English lesson often" (5.7) the students prefer review what they learn before to more understand the lesson infrequently and the lowest is for "I use flashcards to remember new English words" (2) the students have less interest in using flashcard to remember new English word it is like they did not want to try a new method of learning. The result of the questionnaire analysis related to Cognitive strategies used by the students are shown in table 3 :

Table 3. Cognitive strategies used by the students

\begin{tabular}{|c|c|c|}
\hline Strategy & Mean & SD \\
\hline I say or write new English words several times & 3.2 & 1.01 \\
\hline I try to talk like native English speakers & 3.6 & 0.81 \\
\hline I practice the sounds of English & 3.8 & 0.84 \\
\hline I use the English words I know in different ways & 3.65 & 0.51 \\
\hline I start conversations in English & 3.3 & 0.67 \\
\hline I watch English language TV shows or go to movies spoken in English & 3.35 & 0.83 \\
\hline I read for pleasure in English & 3.31 & 0.58 \\
\hline I write notes, messages, letters, or reports in English & 3.45 & 0.92 \\
\hline I first skim an English passage (read it quickly) then go back and read carefully & 3.45 & 1.02 \\
\hline I look for words in my language that are similar to new words in English & 3.25 & 0.67 \\
\hline I try to find patterns in English & 3.1 & 0.82 \\
\hline I find the meaning of any English word by dividing it into parts that I understand & 3.35 & 0.94 \\
\hline I try not to translate word-for-word & 3.1 & 0.54 \\
\hline I make summaries of information that I hear or read in English & 2.6 & 0.72 \\
\hline
\end{tabular}

According to table 3, the students frequently practice the sound of English. They tend not to make summaries of information that heard or read in English. The students use their English words in different ways instead of adding new English words. Some students use the skim technique in reading. They try to translate in form sentences not word by word. The highest score of cognitive strategies is for "I practice the sound of English" (3.8) the students prefer listening to the sound of the English word as the practice to more understand the right pronunciation and word spelling and the lowest are for "I try to find patterns in English" (3.1) in this strategy the students attempt to find various ways in learning English structure of vocabulary use and "I try not to translate word-for-word" (3.1) the students try to translate in the whole sentence rather one by one of the words it would be more acceptable. Compensation strategies that used by the students are listed in table 4:

Table 4. Compensation strategies used by the students

\begin{tabular}{|c|c|c|}
\hline Strategies & Mean & SD \\
\hline To understand unfamiliar English words, I make guesses & 3.3 & 0.56 \\
\hline When I can't think of a word during a conversation in English, I use gestures & 3.9 & 0.77 \\
\hline I make up new words if I do not know the right ones in English & 3.9 & 1.08 \\
\hline I read English without looking up every new word & 2.55 & 1.03 \\
\hline I try to guess what the other person will say next in English & 3.45 & 0.82 \\
\hline If I can't think of an English word, I use a word or phrase that means the same thing & 4.2 & 0.64 \\
\hline
\end{tabular}

Table 4 shows that the most frequent strategies used by the students are 'If I can't think of an English word, I use a word or phrase that means the same thing' and the least strategies that used the students make guessing to understand familiar English words. They use a guess when they don't know unfamiliar words or to understand the word. They use gesture when cannot think while in conversation. The highest score of compensation strategies is for "If I can't think of an English word, I use a word or phrase that means the same thing" (4.2) the students have other alternatives when they did not know about the word in English they would like to use the other phrase or word with the similar meaning and the lowest is for "To understand unfamiliar English words, I make guesses" (3.3) the students try to find another way to understand an unfamiliar word when they learning English with make guesses, this kind of activity make them more express the meaning. Metacognitive strategies used by the students are demonstrated in table 5: 
Table 5. Metacognitive strategies used by the students

\begin{tabular}{|c|c|c|}
\hline Strategies & Mean & SD \\
\hline I try to find as many ways as I can to use my English & 3.7 & 0.66 \\
\hline I notice my English mistakes and use that information to help me do better & 3,8 & 0.54 \\
\hline I pay attention when someone is speaking English & 4.05 & 0.78 \\
\hline I try to find out how to be a better learner of English & 4.4 & 0.82 \\
\hline I plan my schedule so I will have enough time to study English & 3.3 & 0.63 \\
\hline I look for people I can talk to in English & 4.2 & 0.88 \\
\hline I look for opportunities to read as much as possible in English & 3.6 & 0.97 \\
\hline I have clear goals for improving my English skills & 3.55 & 0.74 \\
\hline I think about my progress in learning English & 3.95 & 0.55 \\
\hline
\end{tabular}

Based on the table, the highest score of metacognitive strategies is "I try to find out how to be a better learner of English" with 4.4 points it means that they are more motivated and feel eager to find the ways to shape their ability in learning English. On the other hand, table 5 shows that the least strategies used by the students are that they plan their schedule so they will have enough time to study English. This is because they think hard to manage their time to study and had a lot of other activities since they were in the second year of study.

Table 6. Affective strategies used by the students

\begin{tabular}{|c|c|c|}
\hline Strategies & Mean & SD \\
\hline I try to relax whenever I feel afraid of using English & 3.65 & 0.43 \\
\hline I encourage myself to speak English even when I am afraid of making a mistake & 3.55 & 0.76 \\
\hline I reward myself or treat when I do well in English & 3.05 & 0.52 \\
\hline I notice if I am tense or nervous when I am studying or using English & 3.7 & 0.91 \\
\hline I write down my feelings in a language learning diary & 2.1 & 0.58 \\
\hline I talk to someone else about how I feel when I am learning English & 2.7 & 0.83 \\
\hline
\end{tabular}

Table 6 shows that the most frequent strategies used by students in the affective strategies are they try to relax whenever they feel afraid of using English (3.65) while the least strategies used are they write down their feelings in a language learning diary (2.1). students still try to use English even though there is a fear of making mistakes since the class environment is conducive and the teacher is very supportive of them. On the other hand, the students are not relying on a diary to express their feeling since it might not be in their era anymore to express their feeling in a diary. Students commonly called Millenials and Gen Z is more digital-minded and express their feeling frequently on social media.

Table 7. Social strategies used by the students

\begin{tabular}{lrr}
\hline \multicolumn{1}{c}{ Strategies } & Mean & SD \\
\hline If I do not understand something in English, I ask the other person to slow down or to say it again & 0.76 \\
I ask English speakers to correct me when I talk & 0.2 \\
I practice English with other students & 2.65 \\
I ask for help from English speakers & 3.7 & 0.54 \\
I ask questions in English & 0.5 \\
I try to learn about the culture of English speakers & 3.05 \\
\hline
\end{tabular}

Table 7 highlights the most frequent social strategies used by the students is "If I do not understand something in English, I ask the other person to slow down or say it again". This statement has the highest mean score 4.2 while "I ask for help from English speakers" only gain 2.5 as the least frequently used strategy. This may be reasonable since all students are non-native English speakers and they are not used to hearing a normal speed rate of native speakers. Slowing down the rate is very helpful for them to understand the information delivered by other speakers.

These findings are also confirmed by the result of the interview in which affective strategies are likely to be the least strategies used by students. There might be two main reasons for the rare use of affective strategies: first is that students do not feel the need of using them because they do not have any effective problem. Another reason may be that students suffer from tension or anxiety but they do not use effective strategies because they are not aware of them. Some literature stated that anxiety stems from a low proficiency level (Yen and Chou, 2009; Zare, 2012). More specifically, problems with comprehension, expressing oneself, and insufficient vocabulary knowledge result in tension. It can be seen from the results of the interview that suggests student with the lowest level of effective strategies feels that they are somehow anxious while doing some performance or written test, but they can overcome it. The students reported the following response: 
T: $\quad$ Do you feel anxious while you are learning some language lessons in the classroom?

S1: $\quad$ Yes, because English is not my mother tongue and I haven't known many English. So, it makes me feel an anxious little bit but while I found troubles all people around me are still eager to help me.

This finding is similar to Altunay's (2014) study which shows in her research that the students did not seem comfortable in communicating with others because they have a lack of knowledge in English. But, when they can ask some friends or groups about language problems, they become more relaxed and feel more motivated. In the current study, even if learners avoid sharing feelings related to anxiety, they envy their successful peers and tell this to them. In the second question the learner reported the following:
T: $\quad$ Do you talk to others and share your problems while learning?
S1: Yes, sometimes I talk it to my friends and sister, and I tell to them how difficult it to be understood.
S2: $\quad$ Of course. Particularly when I have to give my opinion or answer well something I can't understand well.
T: $\quad$ Do you write a diary to keep your problem?
S1: $\quad$ No, because I don't like writing in a diary I should tell to my friends.

The results above show that the students tend to use more social strategies in learning English than affective strategies. This finding also supports the study done by Yen and Chou (2009). The students learn certain things and were able to understand English lessons while talking to others (Takeuchi, 2013). The students also pay attention when someone is speaking English. While they know that someone has better English speaking skills than them, they will seek some help to make them understand more about the subject matter (Alhaisoni, 2012). The students are likely eager to find a way to be a better English speaker. This case proves that interaction plays an important role in shaping learners' language skills (Rido and Sari, 2018).

\section{CONCLUSION}

This research investigated the use of language learning strategies by EFL students at the undergraduate level. The findings show that the students use five types of language learning strategies in which metacognitive strategies are the most often used by them followed by social strategies, compensation strategies, cognitive strategies, memory strategies, and at last effective strategy. According to the interview, the students seldom use affective strategies since they do not pay attention too much on emotional factors such as anxiety and nervousness while they are learning English. It was found that the learning atmosphere has been supportive of them and the peers assist them to master the target language. When the students found difficulties in learning they are without doubt shares their problem with others and let their friends help them learn more about the target language. The findings of this research may benefit most from a wide application of teaching methods and strategies in the classroom. Besides this research can be replicable and further elaborated in multiple research contexts. Future research may investigate whether there is a significant difference between language learning strategies use in terms of genders and other factors such as characteristics, motivation, and social background.

\section{REFERENCES}

Aminatun, D. \& Oktaviani, L. (2019). Memrise: Promoting Students' Autonomous Learning Skill through Language Learning Application. Metathesis: Journal of English Language Literature and Teaching, 3(2), 214-223.

Ayu, M. (2018). Interactive activities for effective learning in the overcrowded classroom. Linguists, 4(2), 1-6.

Ayu, M., Diem, C. D., \& Vianty, M. (2017). Secondary school students' English literacy: Use of interactive read aloud instructional strategy. International Journal of Applied Linguistics \& English Literature, 6(7), 292-299

Abdelhalim, M. S. (2015). Children Literature-Based Program for Developing EFL Primary Pupils' Life Skills and Language Learning Strategies. 8 (2) 178-195

Alhaisoni, E. (2012). Language Learning Strategy Use of Saudi EFL Students in an intensive English Learning Context. Canadian Center of Science and Education. 13(8), 115-127

Altunay, D. (2014). Language Learning Strategies Used by Distance learners of English: A Study with a group of Turkish Distance Learners of EFL. Turkish Online Journal of Distance Education (TOJDE), 14(4), 291-305.

Mandasari, B. \& Oktaviani, L. (2018). English Language Learning Strategies: An Exploratory Study of Management and Engineering Students. Premise: Journal of English Education and Applied Linguistics, 7(2), 61-78.

Oxford, R. L. (1990). Language learning strategies: What every teacher should know. New York: Newbury House.

Rido, A., \& Sari, F. M. (2018). Characteristics of classroom interaction of English language teachers in Indonesia and Malaysia. International Journal of Language Education, 2(1), 40-50

Sari, F. M. \& Wahyudin, A. Y. (2019). Blended-Learning: The Responses from Non-English Students in the Indonesian Tertiary Context. Teknosastik: Jurnal Bahasa dan Sastra, 23-28.

-. (2019). Undergraduate Students' Perceptions toward Blended Learning through Instagram in English for Business Class. International Journal of Language Education, 3(1), 64-73. 
Takeuchi, O. (1993). Language learning strategies and their relationship to achievement in English as a foreign language. Language Laboratory, 30, 17-34.

Wahyudin, A. Y. \& Rido. A. (2020). Perceptuals learning styles preferences of international master's students in Malaysia. BAHTERA: Jurnal Pendidikan Bahasa Dan Sastra, 19(1), 95-103. https://doi.org/10.21009/bahtera.191.10.

Wong, L. L. C. \& Nunan, D. (2011). The learning styles and strategies of effective language learners. System, 39, 144-163.

Yen, S. \& Chou, T. (2009). The Effect of MTI on L2 Proficiency and Learning Strategies. Asian EFL Journal, 11(3), 9-28

Zare, P. (2012). Language Learning Strategies among EFL/ESL Learners: A Review of Literature. 5(2), 162-169

\section{BIOGRAPHY OF AUTHORS}

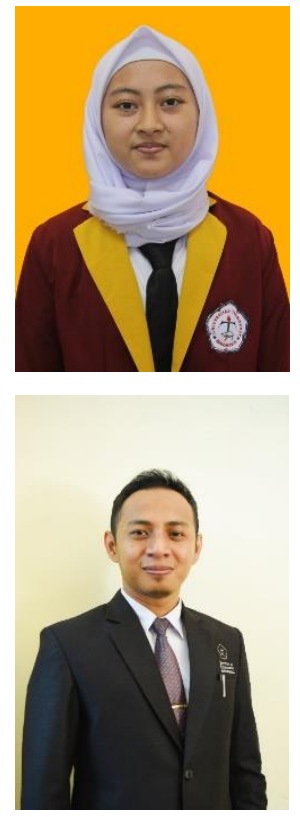

Mega Lestari is a student in the English Education study program, Faculty of Arts and Education, Universitas Teknokrat Indonesia. During her study, she actively joins the students' organization.

Achmad Yudi Wahyudin currently works at Universitas Teknokrat Indonesia as a faculty member at the Faculty of Arts and Education. His research interests include classroom pedagogy, distance learning, curriculum, and material development. 